\title{
Developments in oral health care in the Netherlands between 1995 and 2018
}

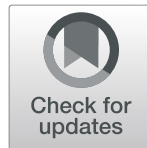

\author{
Joost C. L. den Boer ${ }^{1,2^{*}}$ (D), Wil J. M. van der Sanden ${ }^{3}$ and Josef J. M. Bruers ${ }^{1,2}$
}

\begin{abstract}
Background: Over the past several decades, changes in legislation and regulations have been implemented in oral health care in the Netherlands. In 1995, for example, a major transformation in the funding of oral health care was implemented, after which most oral health care for adults was no longer covered by national insurance. In 1997 , the Individual Healthcare Professions Act, in which the authorizations of care providers were described, was established. The Healthcare Quality, Complaints and Disputes Act, established in 2016, concerns the accountability of professional behavior. Regulations concerning employment have changed several times since 1995. These changes have affected the work and practice situation of oral health care providers.

Methods: Data from many publicly available sources were gathered and combined with internal reports mainly derived from the Data Stations project of the Royal Dutch Dental Association. This project was established in 1995 and, since its initiation, 6716 dentists have participated an average of 6.7 times.

Results: Between 1995 and 2018, nearly all professional groups in oral health care increased, particularly those of dental hygienists and prevention assistants. The number of dental practices decreased, but practices got larger in terms of dental units, number of patients, and personnel. The percentage of inhabitants visiting oral health care professionals remained unchanged, but the type of care provided moved towards more prevention. Oral health care providers exploited new opportunities to enhance and express their professional behavior.
\end{abstract}

Conclusions: Oral health care in the Netherlands has evolved in recent years toward more collaboration in teams, and professions have established institutions to promote the quality and safety of care. Greater emphasis has been placed on prevention of dental diseases. These processes were influenced by new legislation and regulations, demographic changes within professional groups, and other social developments.

Keywords: Legislation and regulations, Competence, Professional development, Remuneration, Funding , Collaboration, Manpower, Work and practice situation, Amount and nature of care

\footnotetext{
* Correspondence: j.c.l.den.boer@acta.nl; j.den.boer@knmt.nl

This manuscript provides a quantitative outline of the developments in oral health care in the Netherlands between 1995 and 2018 with respect to manpower, work and practice situation, and care provided, against the background of changing legislation and regulations concerning competence, professional development, remuneration, and funding. ${ }^{1}$ Department of Social Dentistry, Academic Centre for Dentistry Amsterdam (ACTA), University of Amsterdam and Vrije Universiteit Amsterdam, Amsterdam, The Netherlands

${ }^{2}$ Department of Research \& Information, Royal Dutch Dental Association (KNMT), Utrecht, The Netherlands

Full list of author information is available at the end of the article
}

(c) The Author(s). 2020 Open Access This article is licensed under a Creative Commons Attribution 4.0 International License, which permits use, sharing, adaptation, distribution and reproduction in any medium or format, as long as you give appropriate credit to the original author(s) and the source, provide a link to the Creative Commons licence, and indicate if changes were made. The images or other third party material in this article are included in the article's Creative Commons licence, unless indicated otherwise in a credit line to the material. If material is not included in the article's Creative Commons licence and your intended use is not permitted by statutory regulation or exceeds the permitted use, you will need to obtain permission directly from the copyright holder. To view a copy of this licence, visit http://creativecommons.org/licenses/by/4.0/ The Creative Commons Public Domain Dedication waiver (http://creativecommons.org/publicdomain/zero/1.0/) applies to the data made available in this article, unless otherwise stated in a credit line to the data. 


\section{Background}

In recent decades, changes in legislation and regulations have been implemented in various areas of health care in the Netherlands. These changes have affected the work situation of dentists and other oral health care providers related, in particular, to their competence, the funding of oral care, the collaboration between oral health care providers, and the accountability for professional behaviour.

\section{Competence}

The authorizations of care providers in the Netherlands are formulated in the Individual Healthcare Professions Act (IHPA), which was established in 1997 [1]. Under this act, care providers are divided into different groups. Each group has its own requirements concerning qualifications, authorizations, and responsibilities. Five types of oral health care providers are covered by the IHPA: Oral- and maxillofacial surgeons (OMFSs), orthodontists, dentists, dental hygienists, and dental prostheticians. Dentist is a protected professional title; only persons registered in the IHPA-register are entitled to use this title. This also applies to dental specialists, OMFSs, and orthodontists, for which additional registration requirements apply. A specific group are differentiated dentists, who are not specialists but have specialised in a specific area of dentistry by means of extra training. A differentiation training is recognised by a scientific association, is usually part time, and lasts, on average, 3 years. Some differentiated dentists work exclusively as such, and others also work as general dentists. The Royal Dutch Dental Association (KNMT) recognises eleven differentiations: anxiety counselling dentistry, care for the disabled, endodontology, geriatric dentistry, gnathology, maxillofacial prosthesiology, oral implantology, pedodontology, periodontology, restorative dentistry, sleep medicine dentistry.

Dental hygienists and dental prostheticians are educational titles. For these professions, registration in the register for healthcare providers (IHPA-register) does not apply; however, the professional organisations of both professional groups established a register under private law. A five-year 'task redistribution experiment in oral health care will' start in 2020. In this experiment, dental hygienists are allowed to indicate and treat primary dental carious cavities, administer local anaesthesia, and indicate and take intraoral X-ray without the intervention of a dentist. To make this possible, a temporary extension for oral hygiene will be added to the IHPA-register.

The IHPA is not applicable to dental technicians and dental assistants, who do not have an authorization to provide oral health care independently. Similarly, the IHPA is not relevant to those trained as so-called prevention assistants by means of additional courses, which have been in existence since 1995. Prevention assistants are allowed to treat patients under conditions of task delegation. Table 1 provides an overview of the oral health care providers in the Netherlands, their training and their authorizations.

In two advisory reports, published in 2000 and 2006, task redistribution in oral health care was encouraged [2, 3]. The Advisory Committee on Capacity in Oral Health Care (ACAO) released its advisory report in 2000, in which the focus was mainly on working in teams. According to ACAO, such teamwork would further enhance oral health care in the Netherlands [2]. Within a team, patients are treated by the oral health care provider whose knowledge and experience best match the care needed. The advisory report of the Committee on Innovation in Oral Health Care (CIO), released in 2006, provided advice similar to that of the ACAO but focused more on the further redistribution of tasks, primarily between dentists and dental hygienists [3]. The recommended changes included an expansion of the training curricula and, in the long term, a change in the dentistdental hygienist ratio. Moreover, since 2006, dental hygienists have been directly accessible by patients for the provision of preventive oral health care, without referral by a dentist [4].

\section{Professional accountability}

Since 2007, dentists have had the opportunity to voluntarily register these efforts in the Quality Register for Dentists (QRD) and to make these efforts visible to patients and others [5]. In 2008, the Quality Register for Dental Hygienists (QRDH) was established [5]. Both registers are subject to registration and re-registration requirements in terms of work activity and participation in knowledgeand skill-building activities (continuing professional development). The registration of activities related to knowledge and skills development will eventually become compulsory in the IHPA-register.

Another development in professional practice relates to the prevailing belief that health care providers should base their clinical practice, as much as possible, on the best available evidence. In 2012, the Health Council of the Netherlands recommended, among other things, the development of more evidence-based guidelines and encouraged widespread utilisation of these guidelines [6]. In response to this advice, in 2016, an Institute of Knowledge Translation in Oral Care, called 'het KIMO', was established. This is a national institute dedicated to the development and implementation of clinical practice guidelines to support oral health care providers in the provision of care according to best available evidence [7].

In 2016, important components of the legislation and regulations relating to accountability for professional behaviour were brought together in the Healthcare Quality, 
Table 1 Oral health care professions in the Netherlands

\begin{tabular}{|c|c|c|}
\hline profession & training & authorised treatment (1) \\
\hline dentist & dentistry (MSc) & $\begin{array}{l}\text { reserved procedures: }^{\text {a }} \\
\text { - surgical procedures } \\
\text { - assessment of injections } \\
\text { - administration of anaesthesia } \\
\text { - assessment of intraoral X-rays } \\
\text { - prescription of medicines }\end{array}$ \\
\hline orthodontist & $\begin{array}{l}\text { dentistry (MSc) + specialisation } \\
\text { dento-maxillary orthopaedics }\end{array}$ & $\begin{array}{l}\text { reserved procedures: } \\
\text { - surgical procedures } \\
\text { - assessment of injections } \\
\text { - administration of anaesthesia } \\
\text { - assessment of intraoral X-rays } \\
\text { - prescription of medicines }\end{array}$ \\
\hline $\begin{array}{l}\text { oral and maxillofacial } \\
\text { surgeon }\end{array}$ & $\begin{array}{l}\text { dentistry }(\mathrm{MSC})+\text { medicine }(\mathrm{MSC})+\text { specialisation oral } \\
\text { and maxillofacial surgery }\end{array}$ & $\begin{array}{l}\text { reserved procedures: } \\
\text { - surgical procedures } \\
\text { - assessment of injections } \\
\text { - administration of anaesthesia } \\
\text { - assessment of intraoral X-rays } \\
\text { - prescription of medicines }\end{array}$ \\
\hline dental hygienist & dental hygiene (BSc) & $\begin{array}{l}\text { without referral or delegation: } \\
\text { - dental cleaning } \\
\text { practical autonomy: }{ }^{\text {b }} \\
\text { - assessment of ionising radiation as part of examination } \\
\text { - assessment of local anaesthesia by injection } \\
\text { - treatment of primary cavities by preparation as part of restauration } \\
\text { using mouldable materials }\end{array}$ \\
\hline dental prosthetist & dental prosthetics (BSC) & $\begin{array}{l}\text { without referral or delegation: } \\
\text { - assessing dental prosthesis }\end{array}$ \\
\hline prevention assistant & $\begin{array}{l}\text { dental assistant (vocational education) + training } \\
\text { prevention assistant }\end{array}$ & only delegated procedures ${ }^{c}$ \\
\hline dental assistant & dental assistant (vocational education) & only delegated procedures \\
\hline dental technician & $\begin{array}{l}\text { dental technician } \\
\text { (vocational education) }\end{array}$ & only delegated procedures \\
\hline
\end{tabular}

\footnotetext{
${ }^{a}$ Reserved procedures are procedures that a professional is authorised to perform autonomously

${ }^{b}$ Practical autonomy applies to procedures a professional can perform after referral according to protocol. Both referrer and performer must ascertain the competence of the performer. The patient must give consent for treatment by performer

' When delegated procedures are performed, the delegating professional must always be available to intervene or assist when necessary. Both delegating professional and performer must ascertain the competence of the performer
}

Complaints, and Disputes Act (HQCDA) [8-10]. HQCDA focuses primarily on actions taken when something goes wrong in the provision of care. For example, under HQCDA, care providers are required to be affiliated to a complaint procedure. However, professional accountability also implies making efforts to keep one's knowledge and skills up to date.

\section{Remuneration}

In general, there are three ways in which dentists are remunerated in the Netherlands; these are through practice ownership, through independent contracting, and through an employment contract. The laws and regulations concerning self-employment, including independent dentists without their own practice, have been changed a number of times in recent years. These changes were brought about due to the fact that the proportion and number of self-employed workers in the Dutch labour force increased, but, in many cases, the claim of self-employment was false [11]. In case of false self-employment, a freelance contract is actually an employed contract in disguise, because the selfemployed is highly dependent on a client. However, because of the self-employment construction, the 'selfemployed' cannot invoke employees' rights. This apparent independence of self-employed workers has increased in at least eight European countries [12]. The main objective of the legislation and regulations was to simultaneously enable self-employment and prevent false self-employment [13]. Both independent contractors and dentist practice owners are affected by the changes in legislation and regulations.

\section{Funding}

In 1995, the funding of oral health care for Dutch adults was radically changed [14]. Until then, people who earned less than a certain income were covered for medical and oral health care by a national health insurance. After 1995, the larger part of oral health care for adults was no longer covered by the national health insurance. 
All adult patients had to pay for most oral health care themselves, optionally by means of a voluntary, supplementary insurance. In 2006, this national insurance was replaced by the Health Insurance Act, which currently remains in effect. By this act, all residents of the Netherlands are obliged to take out standard health insurance for a limited range of medical care [15]. This range of care covered by basic insurance is determined by the government. For young residents, up to and including 17 years of age, the basic insurance covers the costs of preventive and curative (primary) oral health care. For adults, the reimbursement for oral health care is limited to prosthetic facilities in the edentulous jaw and dental care for people with severe physical and/or mental disabilities. It should be noted that, from 2008 through 2010, persons up to and including 21 years of age were considered young residents.

Furthermore, maximum rates applied to all oral health care through all years, with the exception of 2012, when an experiment with free price setting was conducted. Although the experiment was originally planned to last 3 years, after 6 months, a decision was made to terminate the experiment after 1 year.

The 1995 change in the funding of oral health care caused major changes for dentists, especially due to the fact that reimbursement for oral health care from the national insurance plan was associated with a mandatory half-yearly routine oral examination. This obligation applied to the vast majority of the adult population. The change in the funding prompted the professional organisation of dentists, KNMT, to initiate a continuous research project to monitor the consequences of this change [16, 17]. The studies in this so-called Data Stations Project (DSP) focus on the amount and nature of oral health care provided, on the work and practice situation of dentists, and on the views of dentists on their professional activity. In 2020, DSP is still active. Data from the project supports KNMT to represent its members and to substantiate its policy. KNMT is not unique in its research activities. In other countries, professional dental associations also encourage initiatives to promote structural research [18-20]. The nature of these research projects varies between countries.

In more than twenty years, via the DSP a multitude of data was collected regarding the changes described above and other subjects. These changes have greatly affect the professional practice of dentists, dental specialists, dental hygienists, and other oral health care providers. In this manuscript, we describe changes in professional practise in several professional groups in oral health care in the Netherlands. Specifically, we explore developments that occurred between 1995 and 2018 regarding: (a) manpower in oral health care, (b) dentists' work and practice situation, and (c) the amount and nature of the care provided in general dental practices.

\section{Methods}

Much of the data were collected within the aforementioned DSP $[16,17]$. Data also come from the KNMT dentists' database, registers of various scientific associations, and studies by the Dutch government.

\section{Data stations project}

Within the DSP, research is carried out on dentists in the Netherlands, both KNMT members and nonmembers. The project consists of four sub-studies, which focus on 'care provided', 'work situation and practice organisation', 'views on professional practice', and 'recently graduated dentists'. All examinations are carried out periodically in samples of dentists that are similarly extracted. Most samples consist (partly) of a panel of dentists who have registered for participation or who have participated in the previous edition of the study. Usually, an additional sample of dentist is added in order to guarantee the size and representativeness of the research sample. Data from three sub-studies were used. These sub-studies are described below.

- For the Dental Consumption Study (DCS), data are collected on the treatments that dentists have performed on a random $25 \%$ sample of their patients. These data have been gathered since 1997, systematic annual data are available from 1998 onwards. This data collection is facilitated by specific modules in the most commonly used software for dental practices in the Netherlands. These modules allow dentists to provide anonymised data on patient characteristics (gender, date of birth an insurance) and the universal codes of the dental treatments performed and claimed.

- The Dental Practice Survey (DPS) is a biannual survey about the work situation and practice organisation of dentists. The survey was first carried out in 1995. Through a questionnaire, dentists are questioned about, among other topics, the number of working hours, the composition of the dental team and patient population, the equipment available in practice, and the workload and waiting times for different types of treatment. Initially, only written questionnaires were used, which were sent out and gathered by post. Since 2011, dentists have also had the opportunity to participate via web survey. However, to date, written responses still exceed the internet response. Therefore, questionnaires are still sent out and gathered by post. Both written and web surveys include a 
respondent number, which can be used to check for double participation.

- The Survey of Recently Graduated Dentists (SRGD) was established in 2007 and is, in principle, conducted every 3 years. In SRGD, recently graduated dentists are asked about their first work experiences as dentists and their plans for future professional practice. Invitations for the first edition of this web-based questionnaire were sent by email to all dentists who had graduated in dentistry from a Dutch university in the 3 years prior to the survey. In the following editions, the 'newly' graduated of these institutions were invited. Due to the length of the questionnaires, the 2018 edition of SRGD was carried out in two phases. The first phase focused on the dentists' assessment of their training; the second part focused on their work situation and their wishes for their future professional practice.

Between 1995 and January 2019, 6716 dentists participated at least once in DSP research. On average, individual dentists participated 6.7 times; thus, the total number of participations surpasses 45,000 . Table 2 provides an overview of the number of editions of and the number of participants in the four sub-studies of the DSP. The results of the individual editions of all DSP studies are reported in internal research reports, in scientific and professional journals and on a website about the Dutch oral health care: www.staatvandemondzorg.nl. In this study, no data were used from the fourth substudy, the so-called Omnibus Survey. This sub-study focusses on 'views on professional practice'.

\section{KNMT dentists' database}

Data on the size and composition of the professional groups of dentists, OMFSs, and orthodontists originate from the KNMT dentists' database, in which information is recorded of all dentists and dental specialists authorised in the Netherlands. This database is filled with data regarding the graduates of all Dutch dentistry trainings, the Register of Dental Specialists, and applications for KNMT membership. For verification purposes, the data are compared with the IHPA-register. Registration in this register is mandatory to be authorised to work as a dentist, OMFS, or orthodontist in the Netherlands. The KNMT database contains background characteristics, including sex, date of birth, date and place of graduation, place of establishment, and registration in QRD. In addition, several types of data related to KNMT membership are kept, including activity within the oral health care sector. However, these data are only reliable for KNMT members. Therefore, the dentists' database does not automatically provide an accurate picture of the sizes of the active professional groups. Therefore, the number of active dentists and dental specialists is defined as a specific part of all dentists and dental specialists in the dentists' database, namely all dentists and dental specialists aged 64 years and younger of whom KNMT knows a home address and/or a work address in the Netherlands.

\section{Other information on oral health care providers}

The data on differentiated dentists are derived from the scientific associations that recognize and register the differentiations in question. These data are not always reported publicly by the associations themselves; in some cases the data were made available to and published by third parties [5, 21-36]. The number of dental practices is a rough estimate based on the number of active dentists and the number of dentists per practice. The number of dental practices affiliated with a dental chain was estimated based on data from www.tandarts.nl. According to the owners, this website offers an overview of all dental practices in the Netherlands. In two news items

Table 2 Overview of data collection in the studies carried out within the Data Stations Project between 1995 and January 2019

\begin{tabular}{|c|c|c|c|c|c|c|c|}
\hline & $\begin{array}{l}\text { start } \\
\text { date }\end{array}$ & $\begin{array}{l}\text { cross- sectio-nal (CS) } \\
\text { and/or longitu-dinal (L) }\end{array}$ & $\begin{array}{l}\text { number } \\
\text { of editions }\end{array}$ & $\begin{array}{l}\text { number of dentists who } \\
\text { participated at least once }\end{array}$ & $\begin{array}{l}\text { mean number of } \\
\text { participations }^{b}\end{array}$ & $\begin{array}{l}\text { mean response } \\
\text { percentage }^{c}\end{array}$ & $\begin{array}{l}\text { mean number } \\
\text { of respondents }\end{array}$ \\
\hline $\begin{array}{l}\text { Dental Consumption } \\
\text { Survey (DCS) }\end{array}$ & $\begin{array}{l}\text { a } \\
1998\end{array}$ & $C S+L$ & 21 & 1.513 & $9,1(6,3)$ & $80,9 \%$ & 653 \\
\hline $\begin{array}{l}\text { Dental Practice Survey } \\
\text { (DPS) }\end{array}$ & 1995 & $C S+L$ & 29 & 3.500 & $3,8(4,7)$ & $54,1 \%$ & 454 \\
\hline Omnibus Survey & 1995 & CS & 40 & 3.858 & $4,4(5,3)$ & $56,6 \%$ & 427 \\
\hline $\begin{array}{l}\text { Survey of Recently } \\
\text { Graduated Dentists } \\
\text { (SRGD) }\end{array}$ & 2007 & $C S+L$ & 4 & 998 & $1,1(0,4)$ & $34,1 \%$ & 286 \\
\hline Total & 1995 & $C S+L$ & 94 & 6.716 & $6,7(8,5)$ & e $60,3 \%$ & e 480 \\
\hline
\end{tabular}

${ }^{\mathrm{a}}$ First year of digital data collection

b Standard deviation in parentheses

c Calculated on the basis of the mean of the response percentages of all individual editions

d Calculated on the basis of the mean number of respondents of all individual editions

e Calculated on the basis of the figures in this table 
on this website, the total number of dental practices listed is stated as well as the percentage of these practices that are affiliated with a dental chain $[37,38]$.

\section{CBS data}

Data on the number of inhabitants of the Netherlands, their oral health care status, and their visits to oral health care providers were derived from the Central Bureau of Statistics (CBS) [39]. As are data on total expenditures oral health care and gross domestic product (GDP) [39]. CBS is the government body responsible for the collection and maintenance of statistical data. CBS has access to data from the digitalised population records of all municipalities and therefore can provide information about the number of inhabitants of the country. Based on this number and on data from the KNMT dentists' database, the number of inhabitants per dentist was calculated.

Data on the number of visits to dentists, orthodontists, and dental hygienists were retrieved from the CBS Health Survey, an annual survey among a sample of 15, 000 inhabitants of the Netherlands. From 1997 to 2009, this survey was part of the Permanent Survey of Living Conditions.

\section{Results}

\section{Professional groups in oral health care}

Table 3 shows that the number of dentists and dental specialists in the Netherlands aged 64 years and younger increased between 1995 and 2018, as did the number of dental hygienists and dental prostheticians. The number of dental technicians decreased during this period. The combined number of dental and prevention assistants increased in the aforementioned period, and, within this group, the proportion of prevention assistants grew. In many cases, prevention assistants work in a combined form, as they also perform tasks as a dental assistant.

In 2000, four dental differentiations were recognised by KNMT: periodontology, maxillofacial prosthesiology, gnathology, and endodontology. Since then, seven more differentiations have been recognised: oral implantology, care for the disabled, geriatric dentistry, pedodontology, anxiety counselling dentistry, sleep medicine dentistry, and restorative dentistry. This extension of differentiations has led to an increase in the number of differentiated dentists.

Furthermore, the composition of the professional group of dentists has changed. The proportion of female dentists has increased since 1995. The age distribution has also changed over the years. Between 2001 and 2016 , the proportion of dentists aged 60 or older increased from 6 to $16 \%$, while the proportion of dentists aged 39 years or younger also increased between 2006 and 2018: from 26 to 37\%. Proportionally, the middle age groups have become smaller. It is also striking that the proportion of dentists who graduated outside the Netherlands increased from 5 to 16\% between 2001 and 2018.

\section{Practice organisation and collaboration}

Over the years, dental practices have grown in size, and dental teams have expanded. Table 4, for example, shows that the average number of treatment units per practice has increased. The number of patients attending dental practices has increased accordingly, as well as the number of care providers and other employees. Whereas the size of practices increased, the number of practices decreased. Furthermore, in recent years, more practices have affiliated with a so called dental chain. The enthusiasm of recently graduated dentists to start their own practice seems to have declined. In 2007, 69\% of then recently graduated dentists expressed a wish to eventually become a practice owner; in $2018,54 \%$ did.

\section{Care provided and funding}

Table 5 shows that, between 1996 and 2018, the number of inhabitants of the Netherlands increased from 15.5 million to 17.2 million. As the proportion of people with natural dentition also increased during this period, the total number of people with natural dentition increased more than the number of inhabitants. Moreover, the proportion of inhabitants contacting a dentist was rather stable between 2001 and 2018, fluctuating between 75 and $80 \%$ per year. In addition, in 2016 and 2018, about one third of the inhabitants of the Netherlands aged 12 years and older visited a dental hygienist, and $8 \%$ of those aged 8 years or older visited an orthodontist.

The total costs for oral health care increased by about 1.4 billion Euro between 1996 and 2018, to a total of almost 2.9 billion Euro. The relative costs for oral health care also increased, especially between 2001 and 2016 .

In recent decades, there has been a change in the type of oral health care provided. In 1998, about one third of all patients were charged for prevention; by 2018, about two thirds of all regular patients were charged for prevention In this period, the proportion of patients charged for curation, declined from 48 to $43 \%$. In this comparison the care to non-regular patients, who visited the practice for emergency care and treatment of pain complaints, was excluded.

\section{Professional accountability}

In 2011, 4 years after its foundation, $40 \%$ of dentists were registered in the QRD. The proportion of dentists registered in the QRD increased to $51 \%$ in 2016 and remained the same after that year. No data are available on registrations in the QRDH. The number of hours 
Table 3 Developments in professional groups in oral health care in the Netherlands between 1995 and 2018

\begin{tabular}{|c|c|c|c|c|c|c|}
\hline & 1996 & 2001 & 2006 & 2011 & 2016 & 2018 \\
\hline number of dentists & 6.887 & 7.397 & 7.994 & 8.590 & 8.656 & 8.794 \\
\hline proportion of female dentists & $18 \%$ & $21 \%$ & $26 \%$ & $32 \%$ & $40 \%$ & $43 \%$ \\
\hline proportion of dentists aged 39 years or younger & nda & $28 \%$ & $26 \%$ & $31 \%$ & $35 \%$ & $37 \%$ \\
\hline proportion of dentists $40-49$ years & nda & $38 \%$ & $32 \%$ & $21 \%$ & $19 \%$ & $20 \%$ \\
\hline proportion of dentists $50-59$ years & nda & $28 \%$ & $34 \%$ & $34 \%$ & $30 \%$ & $27 \%$ \\
\hline proportion of dentists 60 years or older & nda & $6 \%$ & $8 \%$ & $14 \%$ & $16 \%$ & $16 \%$ \\
\hline proportion of dentists who graduated abroad ${ }^{a}$ & nda & $5 \%$ & $7 \%$ & $10 \%$ & $14 \%$ & $16 \%$ \\
\hline \multicolumn{7}{|l|}{ dental specialists } \\
\hline orthodontists & 255 & 287 & 283 & 317 & 318 & 326 \\
\hline oral and maxillofacial surgeons & 194 & 198 & 214 & 245 & 273 & 289 \\
\hline \multicolumn{7}{|l|}{ differentiated dentists ${ }^{b}$} \\
\hline periodontologists & 44 & 61 & $80^{b}$ & 84 & 81 & 87 \\
\hline dentists for maxillofacia prosthetics & nda & nda & nda & 39 & 33 & 46 \\
\hline gnathologists & nda & 45 & $47^{b}$ & 52 & 42 & 54 \\
\hline endodontologists & nda & 26 & $37^{b}$ & 64 & 87 & 92 \\
\hline oral implantologist & - & - & $188^{b}$ & 448 & 345 & 307 \\
\hline dentists for disabled patients & - & - & nda & 35 & 22 & 30 \\
\hline geriatric dentists & - & - & 15 & 18 & 17 & 19 \\
\hline pedodontologists & - & 14 & nda & 41 & 51 & 56 \\
\hline anxiety counselling dentists & - & - & 1 & 27 & 16 & 16 \\
\hline sleep medicine dentists & - & - & - & nda & 116 & $125^{b}$ \\
\hline restorative dentists & - & - & - & - & $35^{\# 2}$ & $36^{b}$ \\
\hline \multicolumn{7}{|l|}{ other oral health care providers } \\
\hline dental hygienists & $1.489^{b}$ & $1.789^{b}$ & 2.267 & $2.425^{b}$ & $3.216^{b}$ & $3.500^{b}$ \\
\hline dental prosthodonitists & nda & nda & $293^{b}$ & $350^{b}$ & $330^{b}$ & $600^{b}$ \\
\hline dental technicians & nda & nda & nda & $5.000^{b}$ & $4.700^{b}$ & $4.700^{b}$ \\
\hline prevention assistants & nda & nda & $2.375^{b}$ & $6.300^{b}$ & $7.650^{b}$ & $8.000^{b}$ \\
\hline dental assistants $^{c}$ & $8.533^{b}$ & nda & $14.125^{b}$ & $11.900^{b}$ & $11.700^{b}$ & $11.200^{b}$ \\
\hline number of inhabitants $(\times 1.000 .000)$ & 15,5 & 16,0 & 16,3 & 16,7 & 17,0 & 17,2 \\
\hline number of inhabitants per dentist ${ }^{\mathrm{a}}$ & 2.250 & 2.161 & 2.043 & 1.939 & 1.962 & 1.954 \\
\hline
\end{tabular}

${ }^{a}$ Including dentists for whom the place of graduation is not registered by KNMT; in practice, this nearly always applies to dentists who graduated outside the Netherlands

${ }^{\mathrm{b}}$ The data refer to the previous year

c Excluding prevention assistants

- Differentiation was not yet recognised by KNMT

nda No data available

dentists spend per month on quality-enhancing activities remained fairly stable between 2001 and 2011 .

\section{Discussion}

The results described above show that the professional practice of oral health care providers has changed in several respects in recent decades. These changes can be linked to social developments within the health care sector in the areas of competence, professional development, remuneration, and funding.

\section{Manpower, work, and practice situation}

The IHPA offers various opportunities for referral and task delegation. Within oral health care, response to these opportunities by care provider has results in a substantial increase in collaboration in the provision of oral health care in the Netherlands. Oral health care is no longer provided mainly by general dentists; instead, care is also provided by differentiated dentists, dental hygienists, prevention assistants, and dental prostheticians. Two advisory committees saw the expansion of collaboration as an opportunity to improve the quality of care 
Table 4 Development in dental practices and collaboration in oral health care in the Netherlands between 1995 and 2018

\begin{tabular}{|c|c|c|c|c|c|c|}
\hline & 1996 & 2001 & 2006 & 2011 & 2016 & 2018 \\
\hline number of dental practices & 5.700 & 5.700 & 5.800 & $5.600^{a}$ & $5.100^{a}$ & 4.600 \\
\hline number of dental units per dental practice & $\begin{array}{l}1,3^{\mathrm{a}} \\
(1,3-1,4)\end{array}$ & $\begin{array}{l}2,0 \\
(1,9-2,2)\end{array}$ & $\begin{array}{l}2,3 \\
(2,2-2,5)\end{array}$ & $\begin{array}{l}2,5 \\
(2,3-2,7)\end{array}$ & $\begin{array}{l}3,1 \\
(2,7-3,5)\end{array}$ & $\begin{array}{l}2,8 \\
(2,6-3,0)\end{array}$ \\
\hline number of 'regular' patients per dental practice ${ }^{b}$ & $\begin{array}{l}2.283^{a} \\
(2.185- \\
2.380)\end{array}$ & $\begin{array}{l}2.703 \\
(2.518- \\
2.888)\end{array}$ & $\begin{array}{l}2.899 \\
(2.689- \\
3.109)\end{array}$ & $\begin{array}{l}2.916 \\
(2.710- \\
3.122)\end{array}$ & $\begin{array}{l}3.298 \\
(2.783- \\
3.812)\end{array}$ & $\begin{array}{l}3.000 \\
(2.722- \\
3.278)\end{array}$ \\
\hline number of patients visiting per week per dental practice & $\begin{array}{l}130^{a} \\
(123-136)\end{array}$ & $\begin{array}{l}141 \\
(130-151)\end{array}$ & $\begin{array}{l}151 \\
(140-163)\end{array}$ & $\begin{array}{l}149 \\
(139-159)\end{array}$ & $\begin{array}{l}169 \\
(141-197)\end{array}$ & $\begin{array}{l}157(139- \\
174)\end{array}$ \\
\hline number of dental practices affiliated with a dental chain & nda & nda & nda & nda & 240 & 325 \\
\hline $\begin{array}{l}\text { proportion of recently graduated dentists who want to become } \\
\text { practice owner }\end{array}$ & nda & nda & $69 \%^{c}$ & $51 \%^{a}$ & nda & $54 \%$ \\
\hline \multicolumn{7}{|l|}{ type of practice (based on collaboration with other dentists) } \\
\hline 1 dentist practice owner, 0 dentist non-owner & nda & $71 \%$ & $63 \%$ & $59 \%$ & $52 \%$ & $44 \%$ \\
\hline 1 dentist practice owner, $1+$ dentist non-owner & nda & $14 \%$ & $18 \%$ & $25 \%$ & $25 \%$ & $23 \%$ \\
\hline $2+$ dentist practice owner, 0 dentist non-owner & nda & $10 \%$ & $14 \%$ & $9 \%$ & $13 \%$ & $21 \%$ \\
\hline $2+$ dentist practice owner, $1+$ dentist non-owner & nda & $5 \%$ & $5 \%$ & $7 \%$ & $10 \%$ & $12 \%$ \\
\hline \multicolumn{7}{|l|}{ proportion of dental practices employing one or more: } \\
\hline dental assistants $^{d}$ & $96 \%$ & $94 \%$ & $89 \%$ & $89 \%$ & $88 \%$ & $90 \%$ \\
\hline prevention assistants $^{\mathrm{d}}$ & nda & $19 \%$ & $45 \%$ & $47 \%$ & $54 \%$ & $54 \%$ \\
\hline dental hygienists & $28 \%$ & $32 \%$ & $35 \%$ & $37 \%$ & $46 \%$ & $52 \%$ \\
\hline secretary/administrative assistants & $31 \%$ & $39 \%$ & $34 \%$ & $46 \%$ & $51 \%$ & $43 \%$ \\
\hline practice managers & nda & $7 \%$ & $19 \%$ & $21 \%$ & $28 \%$ & $25 \%$ \\
\hline dental technicians / dental prostheticians & nda & $3 \%$ & $5 \%$ & $6 \%$ & $6 \%$ & $11 \%$ \\
\hline \multicolumn{7}{|l|}{ proportion of dentists in total practice formation } \\
\hline small $(<=25 \%)$ & nda & nda & $14 \%$ & $12 \%$ & $12 \%$ & $9 \%$ \\
\hline rather small (26-40\%) & nda & nda & $41 \%$ & $41 \%$ & $45 \%$ & $50 \%$ \\
\hline rather large (41-55\%) & nda & nda & $34 \%$ & $36 \%$ & $33 \%$ & $30 \%$ \\
\hline large (> 55\%) & nda & nda & $11 \%$ & $11 \%$ & $10 \%$ & $11 \%$ \\
\hline referral to dental hygienist(s) ${ }^{\mathrm{e}}$ & & & & a & & \\
\hline yes, namely to dental hygienist: ${ }^{f}$ & nda & $86 \%$ & $89 \%$ & $90 \%$ & $91 \%$ & $90 \%$ \\
\hline - within own practice & nda & nda & $33 \%$ & $36 \%$ & $49 \%$ & $55 \%$ \\
\hline - in dental practice of colleague & nda & nda & $11 \%$ & $11 \%$ & $9 \%$ & $13 \%$ \\
\hline - in independent dental hygienist practice & $41 \%$ & nda & $57 \%$ & $60 \%$ & $53 \%$ & $47 \%$ \\
\hline no & nda & $14 \%$ & $11 \%$ & $10 \%$ & $9 \%$ & $10 \%$ \\
\hline delegation to prevention assistant(s) & & & & a & & \\
\hline yes & nda & $59 \%$ & $48 \%$ & $47 \%$ & $52 \%$ & $55 \%$ \\
\hline no & nda & $41 \%$ & $52 \%$ & $53 \%$ & $48 \%$ & $45 \%$ \\
\hline
\end{tabular}

a The data refer to the previous year

b Number of patients who visit the practice at least once a year

c The data refer to the succeeding year

d Until and including 1999, no distinction was made in DPS between dental assistants and prevention assistants

e In 1995, only referral to an independent dental hygienist practice was surveyed. In 2001, the work situation of the dental hygienist to whom dentists referred

was not surveyed

${ }^{f}$ Multiple answers possible, the columns may add up to more than $100 \%$

() Where applicable, 95\%-confidence intervals are presented in between brackets

nda No data available

and solve the shortage of oral health care providers [2, 3]. According to these committees, referral and task delegation would ultimately lead to a reduction in the required number of dentists and an increase in the number of oral hygienists. So far, things have been different. Almost all professional groups in oral health care have 
Table 5 Developments in oral health care provided, expenditure on oral health care, and activities to promote knowledge and skills of oral health care providers in the Netherlands between 1995 and 2018

\begin{tabular}{|c|c|c|c|c|c|c|}
\hline & 1996 & 2001 & 2006 & 2011 & 2016 & 2018 \\
\hline proportion of the population ( 1 year and older) visiting a dentist in the 12 months prior & $74 \%$ & $78 \%$ & $78 \%$ & $78 \%$ & $79 \%$ & $80 \%$ \\
\hline $\begin{array}{l}\text { proportion of the population ( } 12 \text { years and older) visiting a dental hygienist in the } 12 \text { months } \\
\text { prior }\end{array}$ & nda & nda & nda & nda & $32 \%$ & $36 \%$ \\
\hline proportion of the population ( 8 years and older) visiting an orthodontist in the 12 months prior & nda & nda & nda & nda & $7 \%$ & $8 \%$ \\
\hline proportion of inhabitants with own dentitions & $81 \%$ & $84 \%$ & $87 \%$ & nda & nda & nda \\
\hline number of visits to dentists per patient per year & 2,7 & 2,9 & 2,8 & 3,0 & 3,2 & 3,4 \\
\hline number of visits to dentists per inhabitant per year ${ }^{a}$ & 2,0 & 2,3 & 2,2 & 2,3 & 2,6 & 2,8 \\
\hline type of treatment & b & & & & & \\
\hline consultation and diagnostics & $33 \%$ & $30 \%$ & $20 \%$ & $18 \%$ & $17 \%$ & $15 \%$ \\
\hline consultation and diagnostics and prevention & $15 \%$ & $19 \%$ & $27 \%$ & $33 \%$ & $36 \%$ & $37 \%$ \\
\hline consultation and diagnostics and curation & $33 \%$ & $30 \%$ & $20 \%$ & $16 \%$ & $15 \%$ & $14 \%$ \\
\hline consultation and diagnostics and prevention and curation & $15 \%$ & $18 \%$ & $29 \%$ & $29 \%$ & $28 \%$ & $29 \%$ \\
\hline prevention and/or curation (emergency care or treatment of pain complaints) & $4 \%$ & $3 \%$ & $4 \%$ & $4 \%$ & $4 \%$ & $5 \%$ \\
\hline expenditure on oral health care in dental practices ( $\times 1$ million) & nda & 1.519 & 2.025 & 2.682 & 2.877 & 2.897 \\
\hline expenditure on oral health care in dental practices, as a percentage of GDP & nda & $0,32 \%$ & $0,35 \%$ & $0,42 \%$ & $0,39 \%$ & nda \\
\hline proportion of dentists registered in QRD & - & - & - & $40 \%$ & $51 \%$ & $51 \%$ \\
\hline \multicolumn{7}{|l|}{ number of hours per month spent by dentists on activities to promote knowledge and skills: } \\
\hline continuing education & nda & $\begin{array}{l}5,0 \\
(4,6-5,4)\end{array}$ & $\begin{array}{l}4,8 \\
(4,3-5,3)\end{array}$ & $\begin{array}{l}6,3 \\
(5,8-6,8)\end{array}$ & $\begin{array}{l}5,1 \\
(4,4-5,8)\end{array}$ & $\begin{array}{l}4,5 \\
(4,1-5,0)\end{array}$ \\
\hline peer learning exchanges & nda & $\begin{array}{l}1,5 \\
(1,3-1,7)\end{array}$ & $\begin{array}{l}1,7 \\
(1,4-2,0)\end{array}$ & $\begin{array}{l}2,1 \\
(1,9-2,4)\end{array}$ & $\begin{array}{l}1,8 \\
(1,5-2,1)\end{array}$ & $\begin{array}{l}1,4 \\
(1,1-1,6)\end{array}$ \\
\hline reading professional literature & nda & $\begin{array}{l}5,3 \\
(4,8-5,8)\end{array}$ & $\begin{array}{l}4,7 \\
(4,2-5,1)\end{array}$ & $\begin{array}{l}5,0 \\
(4,7-5,4)\end{array}$ & $\begin{array}{l}4,5 \\
(4,1-5,0)\end{array}$ & $\begin{array}{l}4,2 \\
(3,6-4,7)\end{array}$ \\
\hline
\end{tabular}

${ }^{a}$ Including all inhabitants who have not visited the dental practice

${ }^{\mathrm{b}}$ The data refer to 1998

() Where applicable, 95\%-confidence intervals are presented in between brackets nda No data available

grown, and the increase in the number of dental hygienists as well as, in particular, the emergence of prevention assistants stand out. Especially for prevention assistants, opportunities were created by task shifting. JerkovićĆosić et al. found that dental hygienists with four-year training are given a more extensive range of tasks than their colleagues with a two- or three-year training [40]. The increased focus on complex tasks by dental hygienists allows the prevention assistant to carry out the more basic primary and secondary prevention tasks. It is unclear to what extent the current training of dental assistants responds to these possibilities to broaden the range of tasks.

Other factors also provided an incentive for more collaborations. Due to the sharp increase in female students and regionally experienced shortages of dentists, the composition of the dental profession changed. The proportion of female dentists increased significantly, as did the proportion of dentists who graduated outside the Netherlands. In addition, the number of dentists specialising in a specific area of dentistry has increased. Partly because of this changing composition of the profession, the number of dentists active in their own practice decreased. Female dentists and dentists who graduated abroad appear to be less inclined to start their own practices [41-43]. The increased collaboration in larger dental teams has led to the development of larger practices and more affiliation with dental chains, among other things. The fact that, in the last decade, a relatively large number of older dentists have ended their practice, which were, in some cases, difficult to sell, has also contributed to this shift. Moreover, these changes have not yet led to a solution to the problem of dentist shortages. Particularly in certain regions, dentist shortages were reported in 2019 [44].

\section{Care provided}

In the changing landscape of dental practices, the proportion of inhabitants visiting a dentist and/or dental hygienist remained unabatedly high. In fact, this proportion is so high that there is not much room for increase as a proportion of the people do not visit a dentist for various reasons [45]. However, there was a shift to more preventive care. This may be triggered by the 
improved oral health of, especially, Dutch adults, which reduced the need for curative treatment [46]. Attention to quality and safety of care also increased [47]. Evidence-based clinical practice has been better facilitated by the establishment of an independent institute for the development of clinical guidelines within oral healthcare by the oral health care professions [7, 48]. Furthermore, dentists and dental hygienists have increased opportunities to display their efforts to keep their knowledge and skills up to date. A significant proportion of professionals seizes these opportunities. For dentists, this does not seem to elevate (or alleviate) the time they spend on continuing education, participation in study groups, or reading professional literature.

\section{Restrictions}

A large portion of the data used for this study was obtained for DSP and, therefore, primarily concerns dentists. The fact that less information is presented in this study about other professional groups is due to limited availability of data. Moreover, most of the care provided by dental hygienists and prevention assistants is performed in dental practices and therefore included in DCS. For this reason, the consequences of this omission are limited [49].

The developments described only concern the Netherlands and therefore cannot be compared automatically with developments in other countries. After all, legal frameworks differ between countries, as do the ways in which these framework affect the provision of care $[50,51]$. However, the description of specific developments in the Netherlands in recent years may provide insights for other countries. In the Netherlands, for example, the possibilities for task delegation and referral are strongly embedded in legislation and regulations. This study provides a scenario for the consequences of this policy choice for countries where the authorisation of different professional groups is debated. Additionally, there are, of course, also similarities between countries, as certain developments and challenges are cross-border in nature. The focus on evidence-based clinical guidelines and the establishment of an institution to develop them, for example, can be observed in several other countries as can a similar emergence of dental chains [52-56]. Furthermore, in many countries teamwork in oral health care practices is increasing and task redistributions is under consideration or construction [57-59]. In short, this study provides a useful outline of these cross-border developments from a Dutch perspective.

\section{Conclusion}

Influenced by new legislation and regulations, demographic changes within professional groups, and other social developments, oral health care in the
Netherlands has evolved in recent years toward more collaboration in teams, and professions have established institutions to promote the quality and safety of care. In addition, emphasis in the provision of oral health care has been placed even more on prevention of oral diseases.

\begin{abstract}
Abbreviations
ACAO: Advisory Committee Capacity Oral Health Care (In Dutch:

Adviescommissie Capaciteit mondzorg); CBS: Central Bureau of Statistics

(Centraal Bureau voor de Statistiek); ClO: Committee on Innovation in Oral Health Care (Commissie Innovatie Mondzorg); DSP: Datastations Project

(Project Peilstations); GDP: Gross Domestic Product; KNMT: Royal Dutch Dental Association (Koninklijke Nederlandse Maatschappij tot bevordering der Tandheelkunde); QRDH: Quality Register for Dental Hygienists (Kwaliteitsregister Mondhygiënisten); QRD: Quality Register for Dentists (Kwaliteitsregister Tandartsen); SRGD: Survey of Recently Graduated Dentists (Onderzoek Recent afgestudeerde Tandartsen); OMFS: Oral- and maxillofacial surgeon; DCS: Dental Consumption Survey (Onderzoek Tandheelkudndige Consumptie); DPS: Dental Practice Survey(Onderzoek Tandheelkundige Praktijkvoering); IHPA: Individual Healthcare Professions Act (Wet op de beroepen in de individuele gezondheidszorg); HQCDA: Healthcare Quality, Complaints, and Disputes Act (Wet kwaliteit klachten en geschillen zorg)
\end{abstract}

\section{Acknowledgements}

Not applicable.

\section{Authors' contributions}

JDB designed the research, interpreted the data and drafted the manuscript. WDS edited the manuscript. JB designed the research, interpreted the data and edited the manuscript. The authors have read and approved the manuscript.

\section{Funding}

The study was part of the continuous research project DSP, which is funded and commissioned by KNMT board. An independent research committee monitors the quality and ethical aspects of all DSP studies. The data collection was conducted by independent institutes. Researchers are not restricted in their analyses and interpretation of the data. For this paper, no approval of the KNMT board was required.

\section{Availability of data and materials}

The internal research reports are available from the corresponding author upon reasonable request.

\section{Ethics approval and consent to participate}

The study protocol of all DSP surveys, including the questionnaires, sampling and methods of obtaining informed consent, were approved beforehand by the Research Committee of KNMT (In Dutch: Commissie

Onderzoeksbegeleiding). In all editions, dentists eligible for participation received a letter in which the survey was announced and its background explained. By completing and returning the questionnaire (by freepost or email), dentists consented to participate. Data were anonymised before analysis. Information that could be traced back to the dentist who answered the questions was only used for the analyses of the representativeness and for the in- or exclusion in later editions.

\section{Consent for publication}

Not applicable.

\section{Competing interests}

The authors declare that they have no competing interests. WVDS is associate editor of BMC Oral Health.

\section{Author details}

'Department of Social Dentistry, Academic Centre for Dentistry Amsterdam (ACTA), University of Amsterdam and Vrije Universiteit Amsterdam,

Amsterdam, The Netherlands. ${ }^{2}$ Department of Research \& Information, Royal Dutch Dental Association (KNMT), Utrecht, The Netherlands. ${ }^{3}$ Department of 
Dentistry, Quality and Safety of Oral Healthcare, Radboud Institute for Health Sciences, Radboud University Medical Center, Nijmegen, The Netherlands.

\section{Received: 2 September 2019 Accepted: 25 June 2020 Published online: 08 July 2020}

\section{References}

1. Wet op de beroepen in de individuele gezondheidszorg, (2017).

2. Adviesgroep Capaciteit Mondzorg. Eindrapport van de adviescommissie capaciteit mondzorg. Den Haag: Ministerie van Volksgezondheid, Welzijn en Sport; 2000.

3. Commissie Innovatie Mondzorg. Innovatie in de Mondzorg, Advies. Leiden: Instituut voor onderzoek van overheidsuitgaven; 2006.

4. Ministerie van Volksgezondheid Welzijn en Sport. Besluit van 21 februari 2006, houdende wijziging van het Besluit diëtist, ergotherapeut, logopedist, mondhygiënist, oefentherapeut, orthoptist en podotherapeut en van het Besluit functionele zelfstandigheid (wijziging opleiding en deskundigheidsgebied mondhygiënist). Staatsblad van het Koninkrijk der Nederlanden. 2006;14:1-13.

5. Den Dekker J. Sociale Tandheelkunde in de Praktijk. Houten: Prelum; 2016. p. 69-78.

6. Health Council of the Netherlands. Perspectives on Oral health care. The Hague: Health Council of the Netherlands; 2012.

7. Mettes T, Bruers J. Op bewijs gebaseerde praktijkrichtlijnen in de mondzorg: een toekomstperspectief. In: Het tandheelkundig Jaar 2018. Houten: Springer; 2018. p. 317-32.

8. Wijzigingswet Wet cliëntenrechten zorg, enz. Taken en bevoegdheden op het gebied van de kwaliteit van de zorg; 2013.

9. Wet kwaliteit, klachten en geschillen zorg, (2016).

10. Laarman B, Akkermans A. Compensation schemes for damage caused by healthcare and alternatives to court proceedings in the Netherlands-the Netherlands National Report to the 20th general congress of the international academy of comparative law, Fukuoka, Japan, 22-28 July 2018. In: Netherlands reports to the twentieth international congress of comparative law; 2018

11. Hatfield I. Self-employment in Europe. London: Institute for Public Policy Research; 2015.

12. Williams $C$, Horodnic I. Evaluating the prevalence and distribution of dependent self-employment: some lessons from the European working conditions survey. Ind Relat J. 2018;49(2):109-27.

13. Wet uitbreiding rechtsgevolgen VAR, (2004).

14. Van Ouwerkerk W, Vos N. National health services in the Netherlands: its influence on dental care. Ned Tijdschr Tandheelkd. 2001;108:94-7.

15. Zorgverzekeringswet, (2005).

16. Bruers J, Den Boer J, Van Dam B. The data stations project: a monitor of dental practice in the Netherlands. Ned Tijdschr Tandheelkd. 2014;121(06): 345-52.

17. Bruers J, Zeegers $\mathrm{G}$. The data stations project of the Dutch dental association. Adv Dent Res. 2005;18(3):50-2.

18. American Dental Association. Health policy institute; 2019. Available from: https://www.ada.org/en/science-research/health-policy-institute.

19. Hakanen J, Koivumäki J. Engaged or exhausted - how does it affect dentists' clinical productivity? Burn Res. 2014;1 (1):12-8.

20. I'Association Dentaire Français. IFRO, the French Institiute for dental research; 2017. Available from: http://www.adf.asso.fr/en/what-we-do/ifro.

21. Capaciteitsorgaan. Capaciteitsplan 2010: Deelrapport 3 Mondzorg. Utrecht: Capaciteitsorgaan; 2010.

22. Capaciteitsorgaan. Capaciteitsplan 2013: Deelrapport 3 Mondzorg. Utrecht: Capaciteitsorgaan; 2013.

23. Commissie Innovatie Mondzorg. Innovatie in de Mondzorg Bijlagen bij het advies. Leiden: Instituut voor Onderzoek van Overheidsuitgaven; 2006. 2802-2006.

24. Den Dekker J. Mondzorg in sociaal perspectief. Houten: Bohn Stafleu van Loghum; 2008. p. 71-85.

25. Den Dekker J. Mondzorg in sociaal perspectief. Houten: Bohn Stafleu van Loghum; 2012.

26. Den Dekker J. Sociale Tandheelkunde in de Praktijk. Houten: Prelum; 2015. p. 69-78.

27. Gosselink K. Restauratief tandarts erkend in Nederland. Ned Tandartsenbl. 2015;70(12):26-9.
28. Jongbloed-Zoet C, Bol-Van den Hil E, La Riviere-llsen J, Van der SandenStoelinga M. Dental hygienists in the Netherlands: the past, present and future. Int J Dent Hyg. 2012;10(3):148-54.

29. Koninklijke Nederlandse Maatschappij tot bevordering der Tandheelkunde. Werkers in de mondzorg: gedifferentieerde tandartsen Utrecht: Koninklijke Nederlandse Maatschappij tot bevordering der Tandheelkunde; 2017. Available from: https://www.staatvandemondzorg.nl/werkers-in-demondzorg/gedifferentieerde-tandartsen/.

30. Nederlands Vlaamse Vereniging voor Restauratieve Tandheelkunde. Register Restauratief Tandartsen; 2017. Available from: https://nvvrt.com/nvvrtacademy/register-restauratief-tandarts/.

31. Nederlandse Maatschappij tot bevordering der Tandheelkunde. Werkers in de mondzorg. Staat van de mondzorg 2010. Nieuwegein: NMT; 2011. p. 4-23.

32. Nederlandse Vereniging voor Orale Implantologie. NVOI bulletin; 2017. Available from: http://nvoi.nl/nieuws/nvoi-bulletin/.

33. Nederlandse Vereniging voor Tandheelkundige Slaapgeneeskunde. Website NVST; 2017. Available from: www.nvts.nl.

34. Van der Lee I, Batenburg R. Wie ziet de tandprotheticus? Een eerste grootschalige studie naar de bestaande en potentiële klanten van tandprothetici in Nederland; 2014.

35. Van der Velden U. Post-academic dental specialties 18: the graduate programme in periodontology. Ned Tijdschr Tandheelkd. 2008;115:375-7.

36. Wesselink P. Post-academic dental specialties 14: post-academic specialty endodontology. Ned Tijdschr Tandheelkd. 2007;114:406-9.

37. Tandartsketens groeien verder 2016 [Available from: https://www.tandarts. $\mathrm{nl} /$ /nieuws/5618/tandartsketens-groeien-verder.

38. Tandartsketens zetten opmars voort 2018 [Available from: https:/www. tandarts.n1/nieuws/6622/tandartsketens-zetten-opmars-voort.

39. Centraal Bureau voor de Statistiek. Statline 2010 [Available from: https:// opendata.cbs.nl/statline/\#/CBS/nl/.

40. Jerković-Ćosić K, Van Offenbeek M, Van der Schans C. Job satisfaction and job content in D utch dental hygienists. Int J Dent Hyg. 2012;10(3):155-62.

41. Bruers J, Van Dam B. A woman at the chair is nothing out of the ordinary. Dental practice by female dentists in the Netherlands. Ned Tijdschr Tandheelkd. 2017;124:563-9.

42. Van Dam B, Bruers J. Ervaringen van en met buitenslands gediplomeerde tandartsen in Nederland. Onderzoek onder buitenslands gediplomeerden en onder Nederlandse tandartsen. Utrecht: KNMT; 2018.

43. Van Doorne-Huiskes A. Women and work, with a specific focus on doctors and dentists. Ned Tijdschr Tandheelkd. 2017;124:549-54.

44. Capaciteitsorgaan. Tussentijds instroomadvies. Utrecht: Capaciteitsorgaan; 2019

45. Hakeberg M, Wide BU. Dental care attendance and refrainment from dental care among adults. Acta Odontol Scand. 2017;75(5):366-71.

46. Schuller A, Vermaire J, Verrips $\mathrm{G}$. Trends in caries experience of adults in the Netherlands from 1995 to 2013. Ned Tijdschr Tandheelkd. 2017;124:97-102.

47. Sonneveld R, Brands W, Van Der Sanden W, Bronkhorst E, Truin G. Quality of dental care: new ideas of the government. Ned Tijdschr Tandheelkd. 2009; 485:116.

48. Mettes T, Zij|lstra H, Holland P, Ickenroth L, Bruers J. A National Institute for development and implementation of evidence-based clinical practice guidelines in the Netherlands. 2015 IADR/AADR/CADR general session; 03/ 12/2015. Boston: International Association for Dental Research; 2015.

49. Van der Lee I, Batenburg R. De eerstelijns mondzorg door consumenten opnieuw bekeken: NIVEL; 2012

50. Eaton K, Ramsdale M, Leggett H, Csikar J, Vinall K, Whelton H, et al. Variations in the provision and cost of oral healthcare in 11 European countries: a case study. Int Dent J. 2019;69(2):130-40.

51. Kravitz A, Bullock A, Cowpe J, Barnes E. EU manual of dental practice 2015. Cardiffy: The Council of European Dentists; 2015.

52. Bateman G, Saha S. A brief guide to clinical guidelines. Br Dent J. 2007; 203(10):581.

53. Bravo M, San Martín L, Casals E, Eaton K, Widström E. The healthcare system and the provision of oral healthcare in European Union member states. Part 2: Spain. Br Dent J. 2015;219(11):547.

54. O'Selmo E. The history of dental bodies corporate and the role of the BDA in their development. Br Dent J. 2018;225(4):353.

55. O'Selmo E. Dental corporates abroad and the UK dental market. Br Dent J. 2018;225(5):448.

56. Ziller $\mathrm{S}$, Eaton $\mathrm{K}$, Widström E. The healthcare system and the provision of oral healthcare in European Union member states. Part 1: Germany. Br Dent J. 2015;218(4):239. 
57. Dyer T, Robinson P. The acceptability of care provided by dental auxiliaries: a systematic review. J Am Dent Assoc. 2016;147(4):244-54.

58. Nash D, Friedman J, Mathu-Muju K, Robinson P, Satur J, Moffat S, et al. A review of the global literature on dental therapists. Community Dent Oral Epidemiol. 2014;42(1):1-10.

59. Barnes E, Bullock A, Chestnutt I, Cowpe J, Moons K, Warren W. Dental therapists in general dental practice. A literature review and case-study analysis to determine what works, why, how and in what circumstances. Eur J Dent Educ. 2020;24(1):109-20.

\section{Publisher's Note}

Springer Nature remains neutral with regard to jurisdictional claims in published maps and institutional affiliations.

Ready to submit your research? Choose BMC and benefit from:

- fast, convenient online submission

- thorough peer review by experienced researchers in your field

- rapid publication on acceptance

- support for research data, including large and complex data types

- gold Open Access which fosters wider collaboration and increased citations

- maximum visibility for your research: over $100 \mathrm{M}$ website views per year

At $\mathrm{BMC}$, research is always in progress.

Learn more biomedcentral.com/submissions 